\title{
Art as the Manifestation of Embodiment in the Age of Modern Technology
}

\author{
Ferdinand Indrajaya \\ Pelita Harapan University \\ UPH Tower - Lippo Karawaci, Tanggerang 15811, Indonesia \\ ferdinand.indrajaya@uph.edu
}

\begin{abstract}
It is undeniable that modern technology has been penetrating our contemporary life in myriad aspects. From the water we drink, foods we eat, to the installed applications in our phone. Hence modern technology has become one dominating worldview on its own which skips our reflection upon it. Its rapid growth stems from the dismissal of tradition and simultaneously with the tremendous scientific discoveries with its inherent instrumental rationality. It actively participates in serving the irrational dimension of our cybernetics-contemporary life. Thus it is not a neutral ensemble of devices, but normatively-prescriptive directs our being in achieving our goals mechanically. As Heidegger said, it enframes our being in the world in a disembodied fashion. Enframing, is the quintessence of modern technology. Merleau-Ponty, as another ardent critic, also stated that modern technology is essentially manipulative. Under the heading of scientism (and or cybernetics), it anesthetizes humanity as its own manipulandum. Contrasting with such view, art potentially re-attunes our relation with things. From Merleau-Ponty's phenomenological perspective, art (especially painting) powerfully shows the prereflective and embodied contact with the world. This paper is an attempt to show the role of art in a life that has been eclipsed by the modern technological worldview.
\end{abstract}

Keywords: modern technology, enframing, disembodied, painting

\section{MODERN TECHNOLOGY AS A WORLDVIEW - A BACKGROUND}

This first part of the paper is an attempt to mainly concern on how modern technology has become a dominating worldview in the life of our contemporary society. Some understandings from different perspectives will be presented before touching upon the main philosophical concern. This is necessary for exposing two things. First, it is quite challenging for us to come up one absolute interpretation on technology and it would be too ambitious to do that. Secondly, it is an initial stage before touching upon what really matters, which is to expose how problematic it is when modern technology has become one dominating worldview.

The most common interpretation of technology perhaps it is an always changing bag of tricks (like that of magician hat) that helps us to live healthier, happier, therefore we will have more fulfilling lives (Li-Hua, 2009, p. 18). Though it may 
sound rather hedonistic in a vulgar and naïve sense - a life full of enjoyment equals to a fulfilling and meaningful life -, it is the most ordinary interpretation on technology. Many of us understand technology in such way. A business owner, for example, technology is a corporate asset for him to compete with his or her business rivals. Academically, nowadays students may think of technology as software and computer that help them significantly in working on their projects and assignments. Medically, a surgeon understands technology as a crucial part for him or her in conducting a surgery. For a scientist, it is the end product of one's research. As for the smartphone users, which probably make the most of us today, technology is a sophisticated social-global communication tool. Based on those provided examples, we may understand that technology exists for the benefits of human being in dealing with practical problems.

As mentioned previously, defining technology with just few well-chosen words is way too ambitious of a project and a challenging effort indeed. Thomas Hughes, as one of a historian of technology, has once stated that "defining technology in its complexity is as difficult as grasping the essence of politics" (Hughes, 2004, p. 2). It is similar with an attempt to come up with the most objective and universal definition about art, in which it is difficult to pin down the complexity of human expression by only few words. To interpret what art is, what technology is, or what a thing is, we're always wearing a certain spectacle or perspective that is not exactly neutral or totally objective and universal; a perspective which is born out of a specific context or a certain world.

How do a business owner, a scientist, a surgeon, a student describe what technology is, as exemplified, is related with two interpretations from many historians of technology in studying the salient phenomenon of the twentieth century. First, many historians of technology pointing out that the twentieth century have been quite attentive to large technological systems, while the other historians from the same century tend to look at technology from a user's perspective in daily life (Misa, 2009, p. 8). From the former, the large technological systems refer to things such as electricity, industrial production, and transportation. While the latter refers to how do people deal with technology in solving their everyday life's problems. What unifies both interpretations is related to what have been mentioned previously about ordinary understanding on technology in our modern contemporary life: technology is believed to be truly effectively beneficial for us. We judge how great and useful it is in accordance with the criterion of efficiency.

Up until now, treating technology as a means to an end for the benefit of human being is still current to us. But regardless that of socio-historical perspective that configures our common and popular understanding about technology, what is technology quintessentially? Or is our current perspective on technology really touching upon what technology is at its core? Martin Heidegger (1889-1976), in his The Question Concerning Technology (1977), proposed a different insight from 
that of current and popular understanding. According to him, technology is not a mere means per se but "a way of revealing" (Heidegger, 1977, p. 14). The term "technology" itself stems from an ancient Greek techne and it "belongs to bringing forth, to poiesis; it is something poietic" (Heidegger, 1977, p.14). In that sense of the word, technology is a mode of disclosing the uniqueness or singularity of things; it brings things (nature, world, or beings including human being) forth poetically. According to him, we can find this understanding of technē manifested in the forms of art, the arts of the minds and also fine arts.

Nevertheless, the understanding on technology in a sense of techne, is different with technology in a modern contemporary sense; an understanding that took its beginning in the 1750. It was characterized by the rise of machines as means for production, and also since then, the machine has become the only form of meaningful technique (Verene, 2004, p. 241). Modern technology, according to Heidegger, is also a way of revealing. What makes it different from the ancient techne is that modern technology is not understood in a sense of bringing-forth, but challenging-forth. He said that "the revealing that rules throughout modern technology has the character of a setting-upon, in the sense of challenging forth. That challenging happens in that the energy is concealed in nature is unlocked, what is unlocked is transformed, what is transformed is stored up, what is stored up is, in turn, distributed, and what is distributed is switched about ever new. Unlocking, transforming, storing, distributing, and switching about are ways of revealing. But the revealing never simply comes to an end" (Heidegger, 1977, p. 16).

Modern technology represents the manner of interacting in terms of which humans encounter everything within the world as object to be used, to be enforced without limit, and to be manipulated at will (Sabatino, 2007, p. 64). The real or the reality itself is taken up as a standing reserve to be exhausted. It represents the manner in which humans have extended their reach to change, shape and thereby control just about everything we encounter within the world with practically no limit. Modern technology is about control and nothing has meaning if it's not available to be used. Agriculture has been revealed as the mechanized food industry, water is now set upon as a hydroelectric power plant, sun has now been set as solar energy for electricity, while electricity is challenged forth to be the fuel for transportation, and so on.

How the real is revealed as a standing reserved is related to what Heidegger took as the essence of modern technology, which is enframing (Heidegger, 1977, p. 20). What is this enframing means? It's going back again to "the way in which the real reveals itself as standing reserve" (Heidegger, 1977, p. 21). In our contemporary life, enframing has become the most salient vision and conception of life; its worldview. In another way of saying it, enframing as the essence of technology has contaminated our contemporary life. It is as a particular way of being in the world that veils other ways of being in the world. Marshall McLuhan (1911-1980), described that modern technology (manifested as modern media of information) 
has worked us over by altering and shaping the way we see the world (McLuhan, \& Fiore, 2001, p. 26). Modern technology has become the environment itself; the dominating worldview.

In its progress, the development of modern technology is not driven by the complexity of ever renewed inventions. It is driven by deserting life's traditional standards and simultaneously interwoven with the growth of science. David Tabachnick in his book entitled The Great Reversal - How We Let Technology Take Control of the Plane, pointed out the concrete examples from the consequences of modern science and technology's development which stems from the dismissal of tradition. These two exemplified consequences are comprehended under Heideggerian essential understanding of technology as enframing. There are two unsettling and related consequences: the first one is the more obvious one while the second one is the less obvious (Tabachnick, 2013, p. 21). The former refers to the world wars. Instead of treating science and technology as a means to improve the quality of human life, we built and developed a technology to eliminate other fellow human being in a most efficient way. In this case, technology serves human appetites for destruction and power.

The later or the less obvious one refers to human enhancement technology that might be illustrated by the recent discoveries in biotechnology and psychopharmacology. Basically, human enhancement technology or it is also commonly labeled as human augmentation, is an emerging field within medicine and bioengineering that aims to develop technology and techniques for overcoming current limitation of human cognitive and physical abilities (Brey, 2009, p. 169). It's a mode of challenging forth the traditional understanding about the aims of medicine, which is to cure and treat illness. Human enhancement technology aims to challenge, to transcend the human condition beyond a state of mere health and it influenced the way we judge ourselves. How healthy and happy we are, judged from how do we finally choose to undergo certain treatment. Treatment such as stem cell therapy, skin whitening treatment, cosmetic plastic surgery procedure, and so on. This is problematic since these inventions of modern science and technology, try to recalibrate or manipulate our passions; our way of being human.

From those two exemplified consequences, we may say that modern technology is all about desire (Verene, 2004, p. 239). Modern technology has become the manifestation of our wild and unlimited desires to master and dominate other people, the world, and ironically even our own selves. Reason, as an intrinsic aspect in modern technology, "is, and ought only to be the slave of the passions," (Hume, 1978, p. 283) as David Hume (1711 - 1776) said. Through the inherence of instrumental reason and scientism, modern technology has become that of cybernetics. Scientism is an ideology that understands scientific methods as the one and only way for us to achieve the most valid truth. While cybernetics is understood as a purposeful machine and also a model to understand purposeful behavior in living creatures (including us) with its mechanical telos 
(Pickering, 2009, p. 118). It is presenting itself to steer (from the word kybernân) ways of our being in the world for the sake of domination and manipulation. Perhaps, Theodor W. Adorno (1903-1969) and Max Horkheimer (1895-1973), the $20^{\text {th }}$ century philosophers of the Frankfurt School were right when they said that "technological rationale is the rationale of domination itself" (Adorno \& Horkheimer, 1973, p. 121). Touching upon reason means we have intersected with one of the dimensions of human being. It shows that in discussing modern technology is inseparable with a certain conception of man.

\section{THE CONCEPTION OF MAN IN MODERN TECHNOLOGY - THE PROBLEM}

There is no explanation about human society without any description on how do they relate themselves with technology in a sense of technē or the modern contemporary one. Conversely, it is going to be very difficult to describe what technology is without touching upon a certain conception on what human being is. How modern technology reveals reality as mere objects to be exhausted, how its rationale is that of domination, or how reason is apparently slave to passion in the age of modern technology, are all presupposing a certain metaphysical assumption on man. The metaphysical anthropological assumption that is intended to be highlighted here is the one of French philosopher, René Descartes (1596-1650). He is the one that we can consider as the father of modern philosophy. Though he is the father of modern philosophy, it will be too much for us to judge him as the cause of our modern contemporary life with all of its challenges. The further discussion will not cover all aspects from his philosophical views but only the ones that are relevant to our main concern, which is modern technology. The writing on this part is an attempt to show how his philosophical view on man is actually the basis for our modern technological life. In order to do that, we can start from what is philosophy according to René Descartes.

For Descartes, philosophy was not a mere practical wisdom, but more importantly, about wisdom in a sense of gaining true knowledge. It was his fundamental aim to reach a philosophical truth based on reason (Copleston, 1958, p. 67). Through putting an emphasis on the search for true knowledge, we may understand in a very broad sense that his philosophy is an epistemology. There are two philosophical perspectives from Descartes that are orbiting to epistemology that will be put under the discussion here. First, it is related to his view on the significance of method. Second, the discussion will be highlighting his metaphysical " $\mathrm{I}$ ", which is his anthropological conception on person. These two philosophical perspectives are closely correlated with each other and also intimately linked with the role of modern technology as a prominent worldview in our contemporary life.

In his view, method is crucial for us to attain the infallible truth about the real. Method is understood simply as a set of rules. These rules need to be applied as a step-by-step process. According to Descartes, the rules that configure a method 
are rules for employing rightly the natural capacities and operations of the mind (Copleston, 1958, p. 73). Method will be fallacy proof if the rules contained in it are based on the operations of mind or reason; then the rules will be effectively utilized to attain the truth. But then, what did Descartes mean by natural capacities and operations of mind? The answers to this question are intuition and deduction (Copleston, 1958, p. 74). What Descartes meant by intuition is an intellectual seeing or vision which is clear, distinct, and it leaves no room for doubt. Intuition, therefore, is understood as a pure mental activity. Deduction, on the other hand, is described as an inference from facts that are known with certainty. These are the two methods that will orient us to the certainty of knowledge; they are necessary to give us as a sense of security. Certain and secure to be utilized. These methods are also inherent and presupposed in modern technology. In challenging the water forth as a hydroelectric power plant, we need to know some natural fact about water and electricity subsequently we need to apply the deductive reasoning in a form of procedure to be finally manifested as hydroelectric power plant. This is also may be exemplified by our daily use of smartphones. We need to think operationally, procedurally intuitive and deductive to have finally used all the applications installed in it.

There is a certain demand for us to affirm with the reality and truth of the method in technology. We are not really precisely using it since we need to conform ourselves with its technique and procedure; we need to comply to its intrinsic criterion. Nothing is real and nothing is true unless it can be executed through a step by step ordering, formed as a procedure (Verene, 2004, p. 237). As Descartes suggested, by the power of intuition and deductive reasoning, we can overcome the challenges, the mystery of the real, when it is chopped down into parts then working on it procedurally from the simplest to the most complex. To this extent, along with Descartes, we may say that to attain certainty, we need to deal with everything by method. What Descartes did was formulating an intellectual method for attaining the certainty of truth, but what we are doing is actualizing, conducting it daily not only in dealing with our gadget but also in human affairs that is accumulated to what we know as SOP or standard operational procedure. This understanding of 'everything must be done by method for the sake truth' implies a certain anthropological framework on what is precisely human being.

Since method is based on the fundamental operations of mind, and it is the only way to attain the certainty of truth, Descartes' metaphysical conception of man is not secluded from this insight. It is reflected and confirmed by the famous dictum of his, cogito ergo sum (I think therefore I am). The dictum was intended to show that the existence of a person is determined by his or her mind; existing equals thinking. Consequently, human being for Descartes is thinking being. The ' $\mathrm{I}$ ' in Descartes' view is the thinking ' $\mathrm{I}$ ' or the subject. The thinking ' $\mathrm{I}$ ' for Descartes is certain and leaves no room for doubt. For Descartes, I who thinks can doubt the certainty of everything except the I who is thinking (Copleston, 1958, p. 97). The I who thinks that everything is open to be doubted, is itself certain and indubitable. 
As he said, "I am, I exist, is necessarily true each time that I pronounce it, or that I mentally conceive it" (Descartes, 1911, p. 150).

Descartes reduced all the complexity of existing or being human to mind or thought. We may ask then, what about body? Or how is thinking related to body? Through these questions, we are touching upon Descartes' dualistic approach to human being. His philosophical perspective on human being is understood under the banner of mind-body dualism. According to his dualism, mind and body are two distinct substances. These two substances are different in nature and capable of existing apart (Copleston, 1958, p. 116). The body, cybernatically speaking, is considered as a mechanical object that is controlled and steered for the mind to achieve its purpose. The body is substantially an object to the mind, while mind is the subject. How body is related to the mind is understood in subject-object dichotomy.

The thinking ' $\mathrm{I}$ ' in Descartes view on human being is asserted as the essential point of reality. The ratification of human being as thinking being has been crucially promoting the emerging of modern technological life. As exemplified previously, the Cartesian method of mental intuition and deductive reasoning (as applied and necessary in natural science) is inherent in modern technology with the challenging forth as its characteristic. Since the method itself is mind or mental latent, therefore it is the thinking ' $\mathrm{I}$ ' that works on the method and working on the method allows the ' $\mathrm{I}$ ' to master its object (body, nature, the world, and everything that is impermanent). Turn what was opaque, blurry, and mysterious, into something that is certain, clear, and distinct (Verene, 2004, p. 239). It leaves no room for mystery for sure.

The modern technological universe is fully populated by this thinking ' $\mathrm{I}$ ' and it leads to one philosophical problem, namely disembodiment. The problem of disembodiment may be understood in two ways that to a certain extent are actually intersecting. First, modern technology through the inherent thinking ' $\mathrm{I}$ ' is orders everything through technique. It treats the world as an objective standing reserve to be exhausted, to everything this thinking ' $\mathrm{I}$ ' desires since it has what it takes to do that. But this attempt to fulfill all desires results nothing, it always leaves a never ending hollow space in the modern person. We can see this in the world wars and the emerging of human enhancement technology as mentioned previously. The thinking 'I' sees everything as an everlasting problem to be solved through method and technique, therefore the challenging of everything forth is also perpetual. Again, it leaves no room for mystery. More fundamentally, the thinking ' $\mathrm{I}$ ' is cut off from its struggle in life, from the intimate engagement with the world since the world is viewed as a mere standing reserve to be exhausted by method and technique. The modern technology disembodies the relationship between human being with the world. Secondly, based on the way Cartesian ' $\mathrm{I}$ ' treats body as a mere mechanical object, modern technology disembodies our ontological relationship with our concrete body. The most vulgar example of this, again, shown by the progressive development of human enhancement technology. 
In which the body is progressively challenged forth as if the body is detached from us and merely a standing reserve. The Cartesian ' $\mathrm{I}$ ' has been promoting the bodiless floating self. But is that it? Are we all truly a crowd of ghosts in the shell? Is there any other way for us to view the real as not a mere standing reserve? The next part of this paper is an attempt to answer such questions.

\section{ART AS THE EMBODIMENT - A WAY OUT}

This part of the paper is an attempt to show how art, especially painting, may 'save' us from the disembodiment that has been the consequences of living in the modern science and technology era. In order to do this, I will borrow some of the phenomenological insights, mainly, from one French philosopher, Maurice Merleau-Ponty $(1908-1961)$. Phenomenology is an early $20^{\text {th }}$ century philosophical discipline that deals with what appears and simultaneously together with its appearing. It designates that which appears in its very appearing (Lewis \& Staehler, 2010, p. 7). In short, it's a philosophical discipline that studies the 'how to' and 'what is' of things in their appearing. For Merleau-Ponty, his phenomenology is mainly occupied with the problem of perception. His phenomenological view on perception is not like Cartesian one, which is a mental construction.

Perception to Merleau-Ponty is practical involvement with things (Matthews, 2006, p. 21). To perceive something is not to think abstractly or analytical about it but to deal with it directly and concretely. This phenomenological view on perception is simultaneously inseparable with his view on the body. The fundamental characteristic of perception is that it always a bodily one. Perception is always an embodied perception and the body is primordially a perceptual body. First of all, we understand the world around us with and through our body. We're not some floating bodiless consciousness like that of Cartesian. We are our bodies (Carman, 2008, p. 11). Body, from Merleau-Ponty, is a condition of possibility of being in the world. This means that we are belong to a world and simultaneously open to the worlds in and through the body. He stated that "the body is our anchorage in the world" (Merleau-Ponty, 1962, p. 144). Body is not a mere mechanical object to be controlled by the Cartesian thinking ' $\mathrm{I}$ '.

Likewise, Merleau-Ponty's view of the world is also different with the modern science and technology perspective that is founded on the Cartesian thinking ' $\mathrm{I}$ '. The world is not mere a standing reserve, an object to be manipulated and exhausted. It is not before us, but first of all, we are in the world. It is the place in which we live our lives, the world we act in, have feelings and hopes about, as well as the world we are always trying to know about (Matthews, 2006, p. 20). As Merleau-Ponty said himself, "the world is what we perceive" (Merleau-Ponty, 1962 , p. viii). In short, the world is not an objective property but it is the one which constitutes our existence.

Basically, what Merleau-Ponty wanted to promote through his phenomenological account is that our primordial contact with the world through bodily 
perception precedes the reflective and abstract way of seeing the world. This phenomenological account of his on bodily perception is closely related to his account on art, especially painting. His philosophical account on art, likewise his phenomenology, is started precisely from a critical response to Cartesian thinking ' $\mathrm{I}$ ', to Cartesian mind-body dualism. Since the thinking ' $\mathrm{I}$ ' has become the basis for the modern contemporary technology, Merleau-Ponty's phenomenological account on art may be read as also a critical response to it. According to MerleauPonty, modern science and technology "manipulates things and gives up living in them" (Merleau-Ponty, 1964, p. 159). The real (including the concrete body and also the world) exists to be manipulated and constructed. It disembodies our intimate engagement with the world and our own bodies because "it makes its own limited models of things; operating upon these indices or variables to effect whatever transformations are permitted by their definition, it comes face to face with the real world only at rare intervals" (Merleau-Ponty, 1964, p. 159). It treats the real as objects in general, as if they have no meaning to us except as utilities.

This is not the case with an artist or a painter. He or she has a different way of seeing the world and according to Merleau-Ponty, his or her way of seeing or looking at things is not the same with that of Cartesian intellectual way of seeing. It is not seeing in modern technological sense, which is challenging things forth. According to Merleau-Ponty, a painter is truly aware of the enigma of seeing, he or she is aware "that my body simultaneously sees and is seen" (Merleau-Ponty, 1964, p. 162). To see is to be open to a world, to be penetrated and possessed by it. Merleau-Ponty illustrated this way of seeing from a situation that was experienced visually by one Swiss painter, Paul Klee (1879-1940).

"In a forest, I have felt many times over that it was not I who looked at the forest. Some days I felt that the tress were looking at me, were speaking to me...I was there, listening...I think that the painter must be penetrated by the universe and not want to penetrate it...I expect to be inwardly submerged, buried. Perhaps I paint to break out." (Merleau-Ponty, 1964, p. 167)

In seeing, we are possessed by the things that we see, by the world, but at the same time it becomes an annex or prolongation of our selves (Merleau-Ponty, 1964, p. 163). The world is embodied in us, it becomes part of us. When it is expressed in painting, painting becomes the manifestation of our embodiment. Painting is a bodily expression; it's the manifestation of our embodied relation with the world. But then we ask: why painting? As Merleau-Ponty said, it is because the painters take the body with them and lend it while painting (MerleauPonty, 1964, p. 161). In painting, the dichotomy between subject-object, between the one who paints and the painted, is dissolved. This means, to paint is to be painted.

Since the painter responds the world through seeing, he or she brings forth what others do not see. Thereby, a painting "gives visible existence to what profane vision believes to be invisible" (Merleau-Ponty, 1964, p. 166). What has been eclipsed by our modern technological life is revealed differently. What has been 
challenged forth and enframed, brought forth poetically through painting. By making visible of what is invisible, art's highest calling is in helping us to get attuned. It has the power to re-attune our relationship with ourselves and with the world. Re-attuning the relationship that might have been crystalized by a challenging forth characteristics of modern technology.

\section{CONCLUSION}

Modern technology reduces life with its dimensions as a problem and leaves no room for mystery. Problems, as popularly understood, is usually dealt by stating, proposing solutions, analyzing, and accepting or rejecting. Mystery, on the other hand, or what Merleau-Ponty labels it as enigma, is different from problem. As Merleau-Ponty suggests, mysteries can only be named, gestured at, and pondered (Carman, 2008, p. 7). The similarity between problem and mystery is they both deal with the questions of being, time, knowledge, love, and no less profound, death. The difference is in the way we deal with them. Regarding what has been discussed in this paper, I will touch upon the question of death. It is the question that expresses our being as mortal or our finitude.

Treating finitude as a problem that needs to be solved is the nature of modern technology, it is its being. This equals to disengaging the constitutive element of our own very existence. Human augmentation is one way which modern technology deals with our finitude. It challenges forth our finitude and it againsts our being as mortal, or being-unto-death as in Heideggerian term (Demske, 1970, p.2). It is purposefully constructed to forget that what makes our life meaningful is death. We are always in search for meaning because we know that one day we will die. Modern technology through the development of human augmentation, dries out the meaningfulness of life by infecting us with the illusion of "forever young"; the enframing delusional aim for immortality.

Art, on the other hand, embraces life and its finitude as mystery. With its highest calling, art helps us to get attuned with things (Wrathall, 2011, p. 28). Things that may also refer to the finitude of our being as mortal. Art entices us to listen to, in Merleau-Ponty's term, the voice of silence. It purveys an admonition to pause for a while in a life which is accelerated by the advances, noises and glut of modern technologies. To pause means to put ourselves in attunement. It means to listen and inhabit the silence that permeates the world, to get in touch with our prereflective and embodied relationship with the world (Mazis, 2016, p. 7). Lastly, unlike the modern technology, to pause is to embrace our finitude in a poetic sense. A necessary pause as the prelude to one truly meaningful act. Last but not least, this writing doesn't try to fully condemn modern technology per se. This writing is simply an alarm. An alarm to pause ourselves for a while from the hassle dazzle yet comfortable of our contemporary life. 


\section{REFERENCES}

Adorno, Theodor and Max Horkheimer. 1973. Dialectic of Enlightenment, translated by John Cumming. London: Verso.

Brey, Philip. 2009. "Human Enhancement and Personal Identity." In New Waves in Philosophy of Technology, edited by Jan Kyrre Berg Olsen, Evan Selinger, and Søren Riis, 169-185. London: Palgrave Macmillan.

Carman, Taylor. 2008. Merleau-Ponty. London \& New York: Routledge.

Copleston, S. J., Frederick. 1958. A History of Philosophy Volume VII - Descartes to Leibniz. London: Burns Oates \& Washbourne Ltd.

Demske, James M. 1970. Being, Man, and Death - A Key to Heidegger. Kentucky: University Press of Kentucky.

Descartes, Rene. 1911. The Philosophical Works of Rene Descartes - Volume I, translated by Elizabeth Haldance and G.R.T. Ross. Cambridge: Cambridge University Press.

Heidegger, Martin. 1977. “The Question Concerning Technology." In The Question Concerning Technology and Other Essays, translated by William Lovitt. New York: Garland Publishing, Inc.

Hughes, Thomas P. 2004. Human-built World: How to Think about Technology and Culture. Chicago, Ill: University of Chicago Press.

Hume, David. 1978. A Treatise of Human Nature, reprinted from the Original Edition in three volumes and edited, with an analytical index, by L.A. Selby-Bigge, M.A. Oxford: Clarendon Press.

Lewis, Michael and Tanja Staehler. 2010. Phenomenology - An Introduction. New York: Continuum International Publishing.

Li-Hua, Richard. 2009. "Definitions of Technology." In A Companion to the Philosophy of Technology - A Blackwell Companion to Philosophy, edited by Jan Kyrre Berg Olsen, Stig Andur Pedersen, and Vincent F. Hendricks, 18-22. New Jersey: Blackwell Publishing Ltd.

Matthews, Eric. 2006. Merleau-Ponty - A Guide for the Perplexed. New York: Continuum International Publishing.

Mazis, Glen A. 2016. Merleau-Ponty and the Face of the World-Silence, Ethics, Imagination, and Poetic Ontology. New York: SUNY Press.

McLuhan, Marshall and Quentin Fiore. 2001. The Medium is the Massage - An Inventory of Effects. California: Gingko Press Inc.

Merleau-Ponty, Maurice. 1964. "Eye and Mind", translated by Carleton Dallery in The Primacy of Perception - And Other Essays on Phenomenological Psychology, the Philosophy of Art, History and Politics, edited by John Wild, 159-190. Illinois: Northwestern University Press.

Merleau-Ponty, Maurice. 1962. Phenomenology of Perception, translated by Colin Smith. London \& New York: Routledge.

Misa, Thomas J. 2009. "History of Technology." In A Companion to the Philosophy of Technology - A Blackwell Companion to Philosophy, edited by Jan Kyrre Berg Olsen, Stig Andur Pedersen, and Vincent F. Hendricks, 7-17. New Jersey: Blackwell Publishing Ltd.

Pickering, Andrew. 2009. "Cybernetics." In A Companion to the Philosophy of Technology - A Blackwell Companion to Philosophy, edited by Jan Kyrre Berg Olsen, Stig Andur Pedersen, and Vincent F. Hendricks, 118-122. New Jersey: Blackwell Publishing Ltd, 2009.

Sabatino, Charles J. 2007. "A Heideggerian Reflection on the Prospects of Technology," Janus Head 10(1): 64-76.

Tabachnick, David E. 2013. The Great Reversal - How We Let Technology Take Control of the Planet. Toronto: University of Toronto Press. 
Verene, Donald P. 2004. "Persons in a Technological Universe." In Globalization, Technology, and Philosophy, edited by David Tabachnick and Toivo Koivukoski, 235-242. New York: State University of New York Press.

Wrathall, Mark. 2011. “The Phenomenological Relevance of Art”. In Art and Phenomenology, edited by Joesph D. Parry. New York: Routledge. 